\title{
“Would You Like to Talk?" Using Media Use and Interpersonal Communication to Predict Civic Engagement
}

\author{
Wenjing Xie \\ School of Communication and the Arts, Marist College, Poughkeepsie, NY, USA \\ Email:wjjwxie@gmail.com
}

How to cite this paper: Xie, W. J. (2019). "Would You Like to Talk?" Using Media Use and Interpersonal Communication to Predict Civic Engagement. Advances in Journalism and Communication, 7, 19-34. https://doi.org/10.4236/ajc.2019.72002

Received: February 15, 2019

Accepted: June 10, 2019

Published: June 13, 2019

Copyright $\odot 2019$ by author(s) and Scientific Research Publishing Inc. This work is licensed under the Creative Commons Attribution International License (CC BY 4.0).

http://creativecommons.org/licenses/by/4.0/

\section{(c) (7) Open Access}

\begin{abstract}
By adopting the social capital theory, this study explored the role of traditional media use, Internet use, and personal talk in predicting civic engagement. The results from a national survey showed that despite the strong bivariate correlation between civic engagement and Internet access as well as traditional mass media use, when interpersonal talk was controlled, some of the significant relationships disappeared. This study suggested that online information seeking and political use of mass media may facilitate the collective action and have the potential to affect the health of civic society. Implications of the results are discussed.
\end{abstract}

\section{Keywords}

Mass Media Use, Internet Use, Interpersonal Communication, Civic Engagement

\section{Introduction}

There has been a long history in the research of community involvement and civic engagement (Aldrich \& Meyer, 2015; Almond \& Verba 1963; Phua, Jin, \& Kim, 2017). According to the knowledge in this field, active citizens are the basic tenet of democracy in society and mass media are lauded as a critical source of political knowledge (Carpini \& Keeter 1996; McLeod, Rush, \& Friederich 1968). However, recent studies of the impact of communication on community integration show that, in a modern society, individuals, even those living in a highly connected community, can only know a very small number of the neighborhood since they spend most of their leisure time with mass media (Anderson, 1991). Thus, scholars like Putnam (1995) viewed mass media, 
especially the television, as a barrier to civic participation.

The advent of Internet has been the topic regarding its ability to promote civic engagement, with predictions emanating from three camps of scholars (Hyun \& Kim, 2015; Nisbet \& Scheufele 2004; Soon \& Samsudin, 2015). The "mobilizing theorists" argued that the Internet will lead to new forms of campaign participation with a great potential to reach young, well-educated, and isolated citizens, reduce communication costs, and provide direct links to policymakers. "Cyber-skeptics", however, contended either very weak or null effect for Internet on civic engagement. The third one, which Nisbet and Scheufele (2004) called "reinforcement theorists", predicted that the Internet will strengthen and enlarge the gap between the rich resources and the poor resources and only provide novel sources of information for people who are already interested in politics.

Launched in 1965 and continued for three decades, the Youth Socialization Panel Study of the University of Michigan aimed to explore the continuity and change of youth socialization. A national sample of high school seniors was first surveyed in 1965. Subsequent surveys of the same individuals were conducted in 1973, 1982, and 1997. Using this longitudinal data, Jennings and Zeitner (2003) compared those who use Internet and those who do not have access to Internet in 1997. They found that the digital divide remained in place or increased slightly over time and Internet access has positive effects on civic engagement. However, in Jenning and Zeitner's study, the role of mass media in influencing civic engagement was ignored. In addition, their model didn't take into account the interpersonal communication, which has demonstrated mediating function between media use and civic engagement. Therefore, by conducting a secondary analysis of the same data set, this study aims to answer two questions:

RQ 1: To what extent is media use associated with civic engagement?

RQ 1.1: To what extent is the use of mass media associated with civic engagement?

RQ 1.2: To what extent is Internet access associated with civic engagement?

RQ 2: To what extent does personal communication influence civic engagement?

\section{Literature Review}

\subsection{Media Use, Social Capital and Civic Engagement}

In recent years, scholars like Putnam $(1995,2000)$ have popularized the term of Social Capital to describe the basic elements of community life, such as interpersonal trust, norms, and social relations, which provide the means for citizens to cooperate on joint problems. It is seen as the resources that enable people to coordinate collective action and achieve common goals (Shah, McLeod, \& Yoon 2001). The participation in community projects, volunteering activities, and engaging in organizational membership activities reinforce and encourage citizens' civic involvement (Ostrom, 1990; Putnam 1995). 
Mass media have been criticized for depriving people of their social capital. Putnam $(1995,2000)$ put forward the arguments about time displacement, which assumes that people's time is a zero-order game and using media may displace time that was formerly spent on face-to-face social relations. Empirical data also supported this argument. McLeod et al. (1996), for instance, demonstrated that a large proportion of local television news is devoted to local crime stories, taking away from other community-related activities.

However, many recent studies distinguished different purpose of media use and showed that, although the entertainment function of mass media was negatively related to civic engagement, the consumption of hard news generally increases political participation (Nisbet \& Scheufele 2004; Scheufele, Nisbet, \& Brossard, 2003; Moy, Manosevitch, Stamm, \& Dunsmore, 2005; McLeod, Scheufele \& Moy 1999; Kim, Hsu, \& de Zuniga, 2013; Martens \& Hobbs, 2015; Xie, 2014). Specifically, Viswanath et al. (1990) found that civic and political involvement were positively related to subscribing to local and regional newspapers, although not related to subscribing to cable television. According to Smith (1986), newspaper reading is thought to foster political participation by increasing social ties, social networks, as well as the sense of community. Television programs of hard news also have been found to have a positive impact on participation, though to a lesser degree. Nisbet and Scheufele's (2004) study showed that news media have indirect impacts on political participation as mediated by political knowledge and political efficacy. Therefore, this study proposes that:

H1: The use of traditional media for political information will have significantly positive influence on civic engagement.

\subsection{Internet Use and Civic Engagement}

Although the advent of Internet has been seen as the dawn of the real democracy by some optimists, the role of the Internet in the democratic society has been controversial. One body of the research defines the use of Internet depending on how much time people spent on Internet and supports Putnam's time-displacement argument. Kraut et al.'s (1998) longitudinal analysis concluded that the use of Internet like watching television erodes communication with family and friends. They asserted that, "like watching television, using a home computer and the Internet generally implies physical inactivity and limited face-to-face social interaction" (p. 1019). Similarly, Nie and Erbring's (2002) findings detected strong correlations between the time spent online and the decrease in time socializing and attending public events outdoors.

Another body of research conceptualized the use of Internet as the experience with Internet rather than time spent with Internet. Studies linking Internet use and civic engagement have detected nuanced picture depending on the content and the function of the use behavior. For example, empirical data showed that Internet use is positively associated with membership in religious organizations, but not with membership in leisure organizations; compared with non-Internet users, people with Internet access are more likely to belong to at least one com- 
munity organization (Katz, Rice, \& Aspden 2001).

The latest camps of literature conceptualize Internet use into a multi-dimensional concept. Scholars divided online behavior into various types and detected different influence patterns. Contending that the impact of Internet use may increase civic engagement, Kavanaugh and Patterson (2001) demonstrated the positive correlation between online political behavior and organizational and political involvement activities. In general, scholars (Boulianne, 2016; Ekström \& Östman, 2015; Moy et al., 2005; Xie, 2014) contended that Internet users tend to be more politically active and the time one spends online is positively related to traditional community engagement.

Based on the arguments above, this study is hypothesizing:

$\mathrm{H} 2$ : Internet access will positively influence people's civic engagement.

\subsection{Citizen Communication}

Research has indicated that communication among citizens largely mediates the effects of news consumption on civic engagement. In particular, Huckfeldt and Spragues (1995) focused on social communication and highlighted that the conversation about politics with families and friends is a key variable in the chain of the effects of communication on civic engagement. Kim, Wyatt and Katz (1999) tested the influence of the interaction of media use and political conversation on deliberative democracy and found that both news-media use and political conversation are closely and positively associated with the quality of opinions and participatory activities. McLeod et al. (2001) organized the antecedents of participation into what they called a "communication mediation model", testing both the interrelationships among these variables and their direct and indirect effects on participatory behavior. According to this model, the effects of mass media on participation are strong but most of them are indirect. The informational use of mass media influences political participation through the mediation of personal talk and reflections on politics. McLeod, Scheufele and Moy (1999) examined the role of community integration and mass and interpersonal communication in predicting types of local political participation and found some complex picture. Interpersonal discussion has the strongest impact of the three communication variables, and television news use only had modest indirect impact on the two types of participation. More recently, Xie (2014) found interpersonal talk over mobile phone not only increased social capital, but also moderated the relationship between social media use and social capital. Therefore, it is hypothesized that:

H3: Personal talk about politics will play a significant role in predicting civic engagement.

\section{Method}

\subsection{Data}

Data used in this study were gathered through the Youth Socialization Panel Study, which was first conducted by the University of Michigan in 1965 and 
aimed to explore the continuity and change of youth socialization. A national sample of high school seniors and their parents was first surveyed in 1965. Subsequent surveys of the sample were conducted in 1973, 1982, and 1997. Only data in the fourth wave were analyzed in this study.

The original data collection was based on a national probability sample of 1669 high school seniors in 1965 distributed across 97 public and nonpublic schools selected with probability proportionate to size. Of the original 1,669 respondents, 935 survived through the fourth wave. The initial response rate of students was $99 \%$ in 1965. Response rate for Wave IV in 1997 was 84\% (Jennings, Markus, Niemi, \& Stoker, 2005).

\subsection{Measurement}

Internet access was measured through one question: "Do you have access to the Internet or a commercial on-line service such as America Online, Prodigy, or CompuServe?". Totally 463 (50\%) respondents reported they had Internet access at home and 256 (27\%) with no Internet access.

Civic Engagement was broken down into two dimensions: political involvement, volunteerism. Political involvement was measured through six indicators: interest in public affairs, internal political efficacy, external political efficacy, political knowledge, community problem solving, and political activity.

1) Interest in public affairs was tested based on the answer to the question that how much they followed what's going on in government.

2) Internal political efficacy combines two items into one measurement, which includes "whether they think voting is the only way people can have any say about how the government runs things" and "whether they think government seems so complicated that a person cannot really understand what's going on" Higher scores mean greater efficacy.

3) External political efficacy was based on responses to two questions: "I don't think public affairs care much what people like think" and "People like me don't have any say about what the government does", with higher scores meaning higher efficacy.

4) Political knowledge was measured through asking the respondents "About how many years does a US Senator serve?"; "Marshall Tito was a leader in what country"; "Do you happen to know about how many members there are on the United States Supreme Court?"; "During World War II, which nation had a great many concentration camps for Jews?"; "Do you happen to remember whether President Franklin Roosevelt was a Republican or a Democracy?"; "Who succeeded John Kennedy as President?"; "Do you know a country that borders on North or South Vietnam?” (Cronbach's alpha = .75).

5) Community problem solving includes only one dichotomous question: "Do you help with other people in your community to resolve the community problems?"

6) Political activity was a measurement constructed through eight items with 
higher number of activities they attend meaning more politically active. The eight items include voting in the past two presidential elections, trying to persuade others how to vote, displaying a campaign button or sticker, making political donations, doing other campaign work, communicating an opinion to public officials, writing a letter to the editor, and taking part in a demonstration.

Volunteerism was measured through two indicators. One is organizational membership, which was tested through asking the respondents the level of the activities they attend in the following organizations: church-connected groups; lodges or fratental groups, neighborhood clubs or associations; sports teams; informal clubs or groups, business or professional groups, etc. The other indicator was called volunteer activity, which asked the respondents "what kind of volunteer work they do apart from any work they do for pay".

Traditional media use was measured by asking the respondents how often they used newspapers, television, magazines, and radio to "follow public affairs, politics, and the news". The frequency categories include "not at all, 3 - 4 times a month, 2 - 3 times a week, and almost daily".

Personal Talk. One question in the original study was asked as the measurement of personal talk: "Do you talk about public affairs or politics with your family members, your friends, or people where you work?".

\section{Results}

\subsection{Correlations between Internet Access, Media Use, and Civic Engagement}

For political involvement, Internet access was positively related with interest in public affairs $(\mathrm{r}=.15, p<.01)$, internal political efficacy $(\mathrm{r}=.18, p<.01)$, external political efficacy $(\mathrm{r}=.19, \mathrm{r}<.001)$, political knowledge $(\mathrm{r}=.22, p<.001)$, community problem solving $(\mathrm{r}=.14, p<.01)$, and political activity $(\mathrm{r}=.23, p$ $<.001)$.

The bivariate correlations in Table 1 also shows that, with access to the Internet, people are more active in joining in a social organization $(\mathrm{r}=.198, p<.001)$ and participating in volunteer activities $(\mathrm{r}=.133, p<.001)$.

Table 1. Zero-order correlation between civic engagement and predicting variables.

\begin{tabular}{|c|c|c|c|c|c|c|}
\hline & TV & Newspaper & Radio & Magazine & Talk & Internet \\
\hline \multicolumn{7}{|l|}{ Political Involvement } \\
\hline Political interest & $.263^{\star * *}$ & $.339^{* * *}$ & $.244^{* * *}$ & $.295^{\star * *}$ & $.159^{* *}$ & $.152^{\star *}$ \\
\hline Internal efficacy & .038 & $.165^{\star *}$ & $.177^{\star *}$ & $.192^{\star *}$ & $.178^{\star * *}$ & $.179^{\star *}$ \\
\hline External efficacy & .046 & $.125^{\star}$ & .065 & $.123^{\star}$ & $.174^{\star * *}$ & $.193^{\star * \star}$ \\
\hline Knowledge & .049 & $.240^{* * *}$ & $.189^{\star *}$ & $.194^{\star *}$ & $.214^{* * *}$ & $.224^{* * *}$ \\
\hline Community involvement & $.068^{*}$ & $.165^{\star *}$ & $.291^{\star * *}$ & $.179^{\star *}$ & $.134^{\star *}$ & $.139^{\star *}$ \\
\hline Political activity & $.132^{\star *}$ & $.262^{* * *}$ & $.236^{\star * *}$ & $.260^{* * *}$ & $.193^{\star * *}$ & $.231^{\star * *}$ \\
\hline \multicolumn{7}{|l|}{ Volunteerism } \\
\hline Organizational membership & $.093^{\star}$ & $.191^{\star *}$ & $.190^{\star *}$ & $.237^{\star * *}$ & $.198^{\star * *}$ & $.198^{\star * \star}$ \\
\hline Volunteer activity & $-.09^{*}$ & $.095^{\star}$ & $.128^{\star *}$ & $.103^{\star *}$ & $.101^{\star}$ & $.133^{\star *}$ \\
\hline
\end{tabular}

Note: entries are product-moment correlations. N's range from 717 to $933 .{ }^{\star} p<.05^{\star *} p<.01{ }^{\star * *} p<.001$. 
Different from the "time-displacement" theory, which puts the television in the first role in depriving people's social capital, this study shows that watching TV is significantly related to Interest in politics $(\mathrm{r}=.263, p<.001)$, community involvement $(\mathrm{r}=.068, p<.05)$, political activity $(\mathrm{r}=.132, p<.01)$, and organizational membership $(\mathrm{r}=.093, p<.05)$. The only dimension of civic engagement which has negative correlation with watching TV is volunteer activity $(\mathrm{r}=-.09$, $p<.05)$.

Other types of traditional media use such as newspaper, magazine, and radio are more closely related with civic engagement compared with TV (see Table 1).

\subsection{Predicting Political Involvement}

The multiple regression analysis provided a stringent test of the relationship between political involvement and media use after considering the contribution of established demographics and personal talk. Specifically, family income plays a significant role in predicting people's interest in politics and public affairs (be$\mathrm{ta}=.206, p<.001)$. Men are more interest in politics than women (beta $=.124, p$ $<.001)$. As noted in Table 2, these established factors account for a sizable amount of variation in interest in politics (Incremental $\mathrm{R}^{2}=7.4 \%, p<.01$ ). The influence of personal talk about politics and public affairs on interest in politics is still very strong after controlling for demographics (beta $=.230, p<.001$ ).

Table 2. Predicting civic engagement: Political involvement.

\begin{tabular}{|c|c|c|c|c|c|c|}
\hline & $\begin{array}{l}\text { Interest in } \\
\text { publics }\end{array}$ & $\begin{array}{l}\text { Internal } \\
\text { efficacy }\end{array}$ & $\begin{array}{c}\text { External } \\
\text { efficacy }\end{array}$ & $\begin{array}{c}\text { Political } \\
\text { knowledge }\end{array}$ & $\begin{array}{l}\text { Community } \\
\text { involvement }\end{array}$ & $\begin{array}{l}\text { Political } \\
\text { activity }\end{array}$ \\
\hline \multicolumn{7}{|l|}{ Block 1} \\
\hline Income & $.206^{* * *}$ & .028 & $.058^{*}$ & .063 & .083 & .067 \\
\hline Sex & $.264^{\star * \star}$ & $.171^{\star * *}$ & -.017 & $.174^{\star * *}$ & -.015 & $.072^{+}$ \\
\hline Age & .003 & .004 & .029 & .077 & -.040 & .030 \\
\hline Education & .008 & .048 & .034 & .009 & .05 & $.128^{\star *}$ \\
\hline Incremental $\mathrm{R}^{2}$ & $.074^{* *}$ & $.111^{* * *}$ & $.017^{*}$ & $.091^{* * *}$ & $.048^{* * *}$ & $.078^{* * *}$ \\
\hline \multicolumn{7}{|l|}{ Block 2} \\
\hline Talk & $.230^{* * *}$ & $.134^{* *}$ & .032 & $.092^{*}$ & $.135^{\star *}$ & $.150^{* * *}$ \\
\hline Incremental $\mathrm{R}^{2}$ & $.051^{* *}$ & $.023^{*}$ & .007 & $.020^{*}$ & $.090^{* * *}$ & $.045^{* *}$ \\
\hline \multicolumn{7}{|l|}{ Block 3} \\
\hline TV & $.166^{* * *}$ & -.008 & .013 & .074 & .036 & .042 \\
\hline Newspaper & $.265^{\star * *}$ & .009 & $.163^{* * *}$ & $.168^{\star * *}$ & .062 & $.145^{* * *}$ \\
\hline Radio & $.105^{\star \star}$ & .071 & -.003 & .075 & $.136^{\star *}$ & $.136^{* * *}$ \\
\hline Magazine & $.158^{\star * *}$ & .020 & .067 & $.082^{*}$ & $.08^{*}$ & $.113^{* * *}$ \\
\hline Internet & $.147^{\star * *}$ & $.132^{\star *}$ & .047 & $.12^{* *}$ & .022 & .056 \\
\hline Incremental $\mathrm{R}^{2}$ & $.175^{\star * *}$ & .009 & $.049^{* * *}$ & $.058^{\star *}$ & $.037^{\star *}$ & $.072^{* * *}$ \\
\hline
\end{tabular}

Note: Entries are standardized hierarchical regression coefficients of the final equation. $\mathrm{N}$ ranges from 717 to $933 .{ }^{*} p<.05,{ }^{* *} p<.01,{ }^{* * *} p<.001$. 
Different from what the "time-displacement" argument has proposed, both traditional media use and Internet access play positive role in predicting political involvement. The more television people watch, the more interested they are in politics (beta $=.166, p<.001$ ). Reading newspaper and magazine is also helpful to improve people's interest in politics (beta $=.265, p<.001$; beta $=.158, p$ $<.001$, respectively). As a traditional medium, radio is also a strong predictor of people's interest in politics (beta $=.105, p<.01$ ). The influence of Internet access on political interest still remain strong after the controlling (beta $=.147, p$ $<.001)$. Totally, this block of variables explained the most sizable part of the variance of civic engagement in the whole model (Incremental $\mathrm{R}^{2}=17.5 \%, p$ $<.001)$.

In terms of political knowledge, men is significantly more knowledgeable than women in politics (beta $=.174, p<.001$ ). Although other established factors are not significant indicators in the hierarchical model, the block of demographics still accounts for $9.1 \%$ of the variance in political knowledge. The influence of personal talk seems to shrink after the controlling for demographics, but still significant (beta $=.092, p<.05$ ). Among the media variables, although radio plays a significant role on the bivariate level $(r=.189, p<.01$, see Table 1$)$, the effects does not survive the controlling for demographics and personal talk (beta $=.075$, n.s.). Newspaper is the only significant predictor in this bloc (beta $=.168$, $p<.001)$. Surfing on Internet for information also increases people's political knowledge $($ beta $=.12, p<.01)$. Totally, the media factors explained $5.8 \%(p$ $<.01$ ) of the variance of political knowledge.

None of the demographic factor significantly predicts people's political activity with an exception of education, which exerts positive influence (beta $=.128, p$ $<.01)$. Personal talk remains strong influence on political activity in the multiple regression model (beta $=.15, p<.001)$. Except TV, all of the use of traditional media like newspaper (beta $=.145, p<.001)$, radio (beta $=.136, p<.001$ ) as well as magazine (beta $=.113, p<.001$ ) positively predict people's political activity. The significant influence of Internet access on the bivariate level, however, is reduced to the nonsignificant level after controlling for the demographics and personal talk.

For community involvement, although no single factor of social economic status is a significant predictor, they totally explained $4.8 \%(p<.01)$ of the variance of the dependent variable, which is still significant in the whole model. The multiple regression model also shows that the more people talks about politics with family members, friends, and co-workers, the more inclined they are to join to solve the community problem (beta $=.135, p<.01$ ). Although the influence of TV and newspaper diminished after the controlling, radio and magazine still significantly predict the community involvement (beta $=.136, p<.01$; beta $=.08, p<.05$, respectively). But the Internet access is not a significant predictor any more after the controlling. Totally the bloc of media use explained $3.7 \%$ ( $p$ $<.01)$ of the variance in the whole model. 
The dataset shows that men has more internal political efficacy than women (beta $=.171, p<.001)$. The demographics totally account of $11.1 \%(p<.001)$ of the variance of internal political efficacy in the whole model. The influence of personal talk on internal political efficacy $(r=.178, p<.001)$ seems to be attenuated by demographic controls, however, it survives to the final model (beta $=.134,0<.01)$. Although newspaper, radio and magazine have strong correlations with internal political efficacy in the zero-order correlation $(\mathrm{r}=.165, p$ $<.01 ; \mathrm{r}=.177, p<.01 ; \mathrm{r}=.192, p<.01$, respectively), the influence was reduced to nonsignificant level after controlling for demographics and personal talk. The impact of Internet access was strong enough to enter the final model (beta $=.132, p<.01)$

For external political efficacy, the model turns out that people with more income have more external political efficacy (beta $=.058, p<.05$ ). Newspaper is the only significant indicator among all of the four media variables in the whole model (beta $=.163, p<.001$ ). The influence of terlevision, magazine, and personal talk on the bivariate level failed to survive the control for demographics. Internet access is not a significant indicator in the final model, either.

\subsection{Predicting Volunteerism}

The demographics together play a significant role in predicting organizational membership (Incremental $\mathrm{R}^{2}=.05, p<.01$, see Table 3 ), although only education enters the final equation (beta $=.118, p<.05$ ). There also appears to be a

Table 3. Predicting civic engagement: volunteerism.

\begin{tabular}{ccc}
\hline & Organizational membership & Volunteer activity \\
\hline Block 1 & -.018 & -.019 \\
Income & .032 & .004 \\
Sex & .019 & .010 \\
Age & $.118^{*}$ & .075 \\
Education & $.050^{* *}$ & .014 \\
Incremental $\mathrm{R}^{2}$ & & $.079^{*}$ \\
Block 2 & $.084^{*}$ & $.024^{*}$ \\
Talk & $.022^{*}$ & \\
Incremental $\mathrm{R}^{2}$ & & $-.056^{*}$ \\
Block 3 & .023 & $.050^{*}$ \\
TV & $.109^{*}$ & $.115^{* *}$ \\
Newspaper & $.122^{* *}$ & .027 \\
Radio & $.120^{* *}$ & .014 \\
Magazine & $.119^{* *}$ & $.018^{*}$ \\
Internet & $.068^{* * *}$ & $\mathrm{~N}$ \\
Incremental $\mathrm{R}^{2}$ & &
\end{tabular}

Note: Entries are standardized hierarchical regression coefficients of the final equation. $\mathrm{N}$ ranges from 717 to $933 .{ }^{\star} p<.05,{ }^{* *} p<.01,{ }^{* * *} p<.001$. 
tight association between personal talk and the organizational membership (beta $=.084, p<.05)$. Three of the four traditional media use variables also contribute to the final model, though television is not among them. Internet access also enhances the possibility to join in an organization (beta $=.119, p<.01$ ). Variables in this bloc together reached a significant level in the final model (Incremental $\left.\mathrm{R}^{2}=.068, p<.05\right)$.

As demonstrated in Table 3, personal talk is a significant indicator for volunteer activity after the controlling for demographics (beta $=.079, p<.05$ ). Both the negative effect of television (beta $=-.056, p<.05$ ) and the positive effect of radio (beta $=.115, p<.01$ ) survived the controlling for demographics and personal talk and entered the final equation. The relationship between Internet access and volunteer activity, although it is significant on the bivariate level ( $\mathrm{r}$ $=.133, p<.01$ ), was greatly impaired in the multiple regressions. Totally the media variables explained about $1.8 \%$ of the variance in volunteer activity.

\section{Discussion}

\subsection{The Influence of Social Economic Status Factor}

Social status factors such as income, sex, and education have been found to influence the participation in political activities (Carpini \& Keeter, 1996; Schlozman, Verba, \& Brady, 1999) and this study confirms these findings. Those with greater incomes are more interested in politics and have more external political efficacy. Sex also turns out to be a significant indicator of political involvement. Men seem to be more interested in politics and public affairs than women, and they are more knowledgeable in politics. Compared to women, men also have more internal political efficacy and participate more traditional political activity such as voting, doing campaign work, writing to the editor, and taking part in demonstrations. Education has a positive but moderate influence on organizational membership. People with higher education tend to be more likely to attend political activities. This tendency supports Norris's (2001) idea that the "digital divide" between the information rich and the information poor will enlarge the existing gap of civic engagement.

However, the influence of age in this study is not as significant as discovered in previous studies (Shah, McLeod, \& Yoon, 2001) because the respondents were in the same age group in the four waves of the survey. Therefore, the "generation gap" of Internet access and the intersection between the stage of political development and the incorporation of the Internet into one's life, which has been found in previous studies, could not be tested in this study.

\subsection{Internet and Civic Engagement}

This study also found that Internet access is strongly correlated with all of the dimensions of civic engagement on the bivariate level. Some of the impacts suffered from the control for personal communication and were reduced to the nonsignificant level, nevertheless Internet access still strongly and positively 
predicts several dimensions such as internal political efficacy, political knowledge, and organizational membership in the multiple regression analysis. Although this analysis cannot repudiate the argument that Internet is a social withdraw, it vindicates that the use of Internet "retarded, at very the least, any relative lowering of civic engagement predispositions and behaviors", as argued by Jennings and Zeitner (2003: p. 330). These results are related to findings in previous studies that Internet encourages new modes of expression and deliberation, which resulted in considerable civic consequences (Carpini, 2000; Shah, McLeod, \& Yoon, 2001).

\subsection{Mass Media: Not Time-Displacement}

Different from what the "time-displacement" argument and "mean world effect" (Putnam, 1995, 2000) have proposed, it is clear from this study that mass communication facilitates civic participation. Newspapers have strong and robust impacts on political involvement and volunteerism, even after controlling for the demographics and personal communication. Magazines promote people's political knowledge as well as community involvement and urge them to attend political activity and join in social organizations. The influence of radio is also positive and strong enough to predict civic engagement. The only negative effect we detected is that watching TV negatively predicts volunteer activity, which marginally reached the significant level. Thus, Putnam's $(1995,2000)$ caution concerning the deprivation of social capital by mass media calls for our rethinking.

One interesting finding in this study is that the "older" media such as radio, newspaper and magazine play a more significant role than television in influencing people's civic engagement. This finding is different from what previous studies have observed, which demonstrated that the effect of television on civic expression and action apparently rival with that of newspaper (Shah et al., 2005; Shah, McLeod, \& Yoon, 2001). The social status factors may be able to explain this. Newspapers are more likely read by people with higher education and social status. The readership of magazine is socially stratified as well. Television viewers, however, are considerably less selective in terms of social status (Shah, McLeod, \& Yoon 2001). Since our respondents are all around 50-year-old and half of them have a college degree, it makes sense that the influence of the newspaper, radio and magazineis greater than the television, reaffirming McLeod, Scheufele, and Moy's (1999) findings. They found that the path from newspaper use to political knowledge is almost twice as strong as the path between television and knowledge. They explained that television news only raises the awareness of social issues or problems and provides only a limited amount of information for citizens, while print media provides more in-depth interpretation and analysis, triggering more forms of participation.

However, we need to cautiously generalize this result and keep in mind that approximately one-half of the 1997 respondents were around 50 years old. One noticeable phenomenon is that nowadays, only 23 percent of the young adults under 30 read newspapers every day and the viewing rate of the network evening 
news of the same age group is only 18 percent (Ahlers \& Hessen 2005). Thus, we can foresee that, when the young adults begin to replace today's older newspaper reading generations, the influence of traditional mass media on civic engagement we detected in this study needs to be retested.

\subsection{Influence of Interpersonal Communication}

Results also provide support for our hypothesis that personal communication influences civic engagement. It appears that people are informed of political knowledge through mass media, which raises the interest in politics and public affairs. After viewing mass media, people tend toelaborate and argue with people around them about what they have learned through media. Those politically charged personal discussions finally determine their political activities. This result is in agreement with Graber's (1993) analysis that interpersonal communication is a major source of political knowledge.

Our findings also verify that Internet access improves personal communication, which leads to civic engagement. In our study, online information seeking increases people's political efficacy and political knowledge, promotes the community involvement and political activity, and encourages volunteer activity. Thus, besides the exposure to political information, people's sociability is a necessary condition for the collective activities.

This study is important because some scholars have been worried that the use of mass media will deprive people of their time which should have been spent with family or friends or participating civic and political activities (Siraj, 2018). However, this study doesn't provide evidence for this hypothesis. Instead, young people's use of traditional mass media and the Internet can promote their civic engagement and social capital. Such results have implications that educators and parents should provide guidance to young people regarding how to use traditional and online media for information and political reasons. Meanwhile, to increase young people's social capital and civic engagement, educators should also encourage younger generation to talk about politics at school and home.

One of the strengths of this study is that it used data from a national wide survey, Youth Socialization Panel Study. Though this dataset has been studied many times, most of the previous research using this data focused on family and partisan socialization (Janoski \& Wilson, 1995; Lyons, 2017), social interactions and trust (Jennings \& Stoker, 2004; Stolle \& Hooghe, 2004), parental religious socialization (Ammann, 2014), political knowledge or generational politics (Jennings \& Markus, 1984; Jennings \& Niemi, 1981), and Internet use on civic engagement (Jennings \& Zeitner, 2003). No studies have incorporated both media use and interpersonal talk. Thus, this study took an innovative perspective to examine the influence of traditional media use, Internet use, and interpersonal talk.

\section{Conclusion}

This study is trying to explicate more fully the forms of civic engagement and 
show how the communication channels such as mass media, Internet as well as personal talk influence citizens' participation. The observed effects of media use and Internet access on civic engagement indicate that they facilitate the collective action and thus have the potential to affect the health of civic society. Regarding our first research question, the results showed that traditional media use such as newspaper, radio, TV and magazine all made significant contributions to political involvement and civic engagement. Internet access also significantly predicted interest in publics, internal efficacy, political knowledge, and organizational membership. It was worth noting that all such relationships were still significant after controlling for demographics and interpersonal talk, indicating the robust relationships between media use and civic engagement. Regarding our second research question, the results demonstrated that interpersonal talk about politics was a strong predictor for interest in publics, efficacy, political knowledge, community involvement, political activity, and civic engagement.

This study contributes to the body of the research of media use and civic engagement. Contrary to the time displacement hypothesis, this study revealed the opposite relationships between civic engagement, political participation, and media use. Not only did traditional mass media use such as watching TV, reading newspapers or magazines, and listening to radios about politics increase political involvement and volunteerism, but also the new generation of the technology, the Internet exerted similar influences. Moreover, this study considered the impacts of interpersonal talk on civic engagement, a factor that has not been studied by previous research using the Youth Socialization Panel Study. The results indicated that for young people, both mass media use and talk with friends or family about politics can contribute to their civic engagement and political involvement.

However, there are still many aspects to be improved in the future studies. First, we take different dimensions civic engagement as one dependent variable. However, previous studies have shown that political knowledge also plays a strongly mediating role between mass media use and political participation (McLeod, Scheufele, \& Moy, 1999). If it is also true for Internet, the direct effects of Internet access on political participation may diminish to nonsignificant level due to the mediation of political knowledge. Future studies can take this into account and test the more complicated relationship between Internet use and civic engagement.

Second, some scholars have found that different use of traditional media has different impacts on civic engagement. For example, watching news on television promotes civic engagement, while watching soap operas and other entertainment programs make people disengage from the civic world. Therefore, future research can distinguish Internet use based on functions such as information seeking, chatting, or entertainment and examine the different influence Internet exerts on civic engagement under different conditions.

Finally, one of the limitations of this study is that Internet use is only operationalized as Internet access. However, communication scholars have found that 
the use of e-mail and Instant Messenger is more like interpersonal communication, while the Bulletin Board System provides a public sphere and tend to be another form of mass communication. Therefore, future studies can take further steps and examine how different forms of Internet use influence civic engagement differently.

\section{Conflicts of Interest}

The author declares no conflicts of interest regarding the publication of this paper.

\section{References}

Ahlers, D., \& Hessen, J. (2005). Traditional Media in the Digital Age. Nieman Reports, 59, 65.

Aldrich, D. P., \& Meyer, M. A. (2015). Social Capital and Community Resilience. American Behavioral Scientist, 59, 254-269. https://doi.org/10.1177/0002764214550299

Almond, G., \& Verba, S. (1963). The Civic Culture: Political Attitudes and Democracy in Five Nations. Princeton, NJ: Princeton University Press. https://doi.org/10.1515/9781400874569

Ammann, S. (2014). Creating Partisan "Footprints": The Influence of Parental Religious Socialization on Party Identification. Social Science Quarterly, 95, 1360-1380. https://doi.org/10.1111/ssqu.12097

Anderson, B. (1991). Imagined Communities. New York: Verso.

Boulianne, S. (2016). Online News, Civic Awareness, and Engagement in Civic and Political Life. New Media \& Society, 18, 1840-1856. https://doi.org/10.1177/1461444815616222

Carpini, D. (2000). Gen.com: Youth, Civic Engagement and the New Information Environment. Political Communication, 17, 341-349.

Carpini, D., \& Keeter, S. (1996). What Americans Know about Politics and Why It Matters. New Haven, CT: Yale University Press.

Ekström, M., \& Östman, J. (2015). Information, Interaction, and Creative Production: The Effects of Three Forms of Internet Use on Youth Democratic Engagement. Communication Research, 42, 796-818. https://doi.org/10.1177/0093650213476295

Graber, D. (1993). Mass Media and American Politics (3rd ed.). Washington, DC: Congressional Quarterly Press.

Huckfeldt, R., \& Spragues, J. (1995). Citizen, Politics, and Social Communication: Information and Influence in an Election Campaign. New York: Cambridge University Press. https://doi.org/10.1017/CBO9780511664113

Hyun, K. D., \& Kim, J. (2015). Differential and Interactive Influences on Political Participation by Different Types of News Activities and Political Conversation through Social Media. Computers in Human Behavior, 45, 328-334.

https://doi.org/10.1016/j.chb.2014.12.031

Janoski, T., \& Wilson, J. (1995). Pathways to Voluntarism: Family Socialization and Status Transmission Models. Social Forces, 74, 271-292. https://doi.org/10.1093/sf/74.1.271

Jennings, M. K., \& Markus, G. (1984). Partisan Orientations over the Long Haul: Results from the Three-Wave Political Socialization Panel Study. American Political Science Review, 78, 1000-1018. https://doi.org/10.2307/1955804 
Jennings, M. K., \& Niemi, R. (1981). Generations and Politics: A Panel Study of Young Adults and Their Parents. Princeton, NJ: Princeton University Press. https://doi.org/10.1515/9781400854264

Jennings, M. K., \& Stoker, L. (2004). Social Trust and Civic Engagement across Time and Generations. Acta Politica, 39, 342-379. https://doi.org/10.1057/palgrave.ap.5500077

Jennings, M. K., \& Zeitner, V. (2003). Internet Use and Civic Engagement: A Longitudinal Analysis. Public Opinion Quarterly, 67, 311-334. https://doi.org/10.1086/376947

Jennings, M. K., Markus, G., Niemi, R., \& Stoker, L. (2005). Youth-Parent Socialization Panel Study, 1965-1997: Four Waves Combined. Ann Arbor, MI: Interuniversity Consortium for Political and Social Research. https://doi.org/10.3886/ICPSR04037.v1

Katz, E., Rice, R., \& Aspden, P. (2001). The Internet 1995-2000: Access, Civic Involvement, and Social Interaction. American Behavioral Scientist, 45, 405-419. https://doi.org/10.1177/0002764201045003004

Kavanaugh, A., \& Patterson, S. (2001). The Impact of Community Computer Networks on Social Capital and Community Involvement. American Behavioral Scientist, 45, 496-509. https://doi.org/10.1177/00027640121957312

Kim, J., Wyatt, R., \& Katz, E. (1999). News, Talk, Opinion, Participation: The Part Played by Conversation in Deliberative Democracy. Political Communication, 16, 361-385. https://doi.org/10.1080/105846099198541

Kim, Y., Hsu, S. H., \& de Zuniga, H. G. (2013). Influence of Social Media Use on Discussion Network Heterogeneity and Civic Engagement: The Moderating Role of Personality Traits. Journal of Communication, 63, 498-516.

https://doi.org/10.1111/jcom.12034

Kraut, R., Patterson, M., Lundmark, V., Kiesler, S., Mukophadhyay, T., \& Scherlis, W. (1998). Internet Paradox: A Social Technology That Reduces Social Involvement and Psychological Well-Being? American Psychologist, 53, 1017-1031.

https://doi.org/10.1037/0003-066X.53.9.1017

Lyons, J. (2017). The Family and Partisan Socialization in Red and Blue America. Political Psychology, 38, 297-312. https://doi.org/10.1111/pops.12336

Martens, H., \& Hobbs, R. (2015). How Media Literacy Supports Civic Engagement in a Digital Age. Atlantic Journal of Communication, 23, 120-137. https://doi.org/10.1080/15456870.2014.961636

McLeod, J., Daily, K., Guo, Z., Eveland, W., Bayer, J., Yang, S., \& Wang, H. (1996). Community Integration, Local Media Use and Demographic Processes. Communication Research, 23, 179-209. https://doi.org/10.1177/009365096023002002

McLeod, J., Rush, R., \& Friederich, K. (1968). The Mass Media and Political Communication in Quito, Ecuador. Public Opinion Quarterly, 32, 575-587.

https://doi.org/10.1086/267647

McLeod, J., Scheufele, D., \& Moy P. (1999). Community, Communication, and Participation: The Role of Mass Media and Interpersonal Discussion in Local Political participation. Political Communication, 16, 315-336. https://doi.org/10.1080/105846099198659

McLeod, J., Zubric, J., Keum, H., Deshpande, S., Cho, J., \& Stein, S. (2001). Reflecting and Connecting: Testing a Communication Mediation Model of Civic Participation. Paper Presented on the Annual Convention of the Association for Education in Journalism and Mass Communication, Washington DC.

Moy, P., Manosvitch, E., Stamm, K., \& Dunsmore, K. (2005). Liking Dimensions of Internet Use and Civic Engagement. Journalism and Mass Communication Quarterly, 82, 571-586. https://doi.org/10.1177/107769900508200306

Nie, N., \& Erbring, L. (2002). Internet and Society: A Preliminary Report. IT \&Society, 1, 
275-283.

Nisbet, M., \& Scheufele, D. (2004). Political Talk as a Catalyst for Online Citizenship. Journalism and Mass Communication Quarterly, 81, 877-896. https://doi.org/10.1177/107769900408100410

Norris, P. (2001). Digital Divide: Civic Engagement, Information Poverty and the Internet in Democratic Societies. New York: Cambridge University Press. https://doi.org/10.1017/CBO9781139164887

Ostrom, E. (1990). Governing the Commons: The Evolution of Institutional for Collective Action. New York: Cambridge University Press. https://doi.org/10.1017/CBO9780511807763

Phua, J., Jin, S. V., \& Kim, J. J. (2017). Uses and Gratifications of Social Networking Sites for Bridging and Bonding Social Capital: A Comparison of Facebook, Twitter, Instagram, and Snapchat. Computers in Human Behavior, 72, 115-122. https://doi.org/10.1016/j.chb.2017.02.041

Putnam, R. D. (1995). Turning in, Turning out: The Strange Disappearance of Social Capital in America. PS: Political Science \& Politics, 28, 664-683. https://doi.org/10.1017/S1049096500058856

Putnam, R. D. (2000). Bowling Alone: The Collapse and Revival of American Community. New York: Simon\& Schuster Paperbacks. https://doi.org/10.1145/358916.361990

Scheufele, D., Nisbet, M., \& Brossard, D. (2003). Pathways to Participation? Religion, Communication Contexts, and Mass Media. International Journal of Public Opinion Research, 15, 300-324. https://doi.org/10.1093/ijpor/15.3.300

Schlozman, K. L., Verba, S., \& Brady, H. E. (1999). Civic Participation and the Equality Problem (Vol. 528). Washington DC: Brookings Institution Press.

Shah, D., Cho, J., Eveland, W., \& Kwak, N. (2005). Information and Expression in a digital Age: Modeling Internet Effects on Civic Engagement. Communication Research, 32, 531-565. https://doi.org/10.1177/0093650205279209

Shah, D., McLeod, J., \& Yoon. S. (2001). Community, Context, and Community: An Exploration of Print, Broadcast, and Internet Influence. Communication Research, 28, 464-506. https://doi.org/10.1177/009365001028004005

Siraj, A. (2018). Impact of Internet Use on Social Capital: Testing Putnam's Theory of Time Displacement in Urban Pakistan. The Journal of Social Media in Society, 7, 456-468.

Smith, H. (1986). Newspaper Readership as a Determinant of Political Knowledge and Activity. Newspaper Research Journal, 7, 47-54. https://doi.org/10.1177/073953298600700206

Soon, C., \& Samsudin, S. N. (2015). General Election 2015 in Singapore: What Social Media Did and Did Not Do. The Round Table, 105, 171-184. https://doi.org/10.1080/00358533.2016.1154388

Stolle, D., \& Hooghe, M. (2004). The Roots of Social Capital: Attitudinal and Network Mechanisms in the Relation between Youth and Adult Indicators of Social Capital. Acta Politica, 39, 422-441. https://doi.org/10.1057/palgrave.ap.5500081

Viswanath, K., Finnegan, J., Rooney, B., \& Potter, P. (1990). Community Ties in a Rural Midwest Community and Use of Newspapers and Cable TV. Journalism \& Mass Communication Quarterly, 67, 899-911. https://doi.org/10.1177/107769909006700444

Xie, W. (2014). Social Network Site Use, Mobile Personal Talk and Social Capital among Teenagers. Computers in Human Behavior, 41, 228-235.

https://doi.org/10.1016/j.chb.2014.09.042 